\title{
Propagasi Mikro dan Sambung Mikro Jeruk Keprok (Citrus reticulata) Garut Hasil Mutagenesis In Vitro dengan Batang Bawah Japansche Citroen
}

\author{
Micropropagation and Micrografting of Mandarin var. Garut (Citrus reticulata) Derived \\ from In Vitro Mutagenesis with Japansche Citroen as rootstock
}

I Made Arisudana Putra ${ }^{1}$, Agus Purwito ${ }^{1 *}$, dan Mia Kosmiatin ${ }^{1}$

Diterima 17 April 2015 / Diterima 26 Juni 2015

\begin{abstract}
This study was aimed at obtaining the best concentration of kinetin for multiplication of Mandarin var. Garut as the derived from in vitro mutation, determining period of immersion of

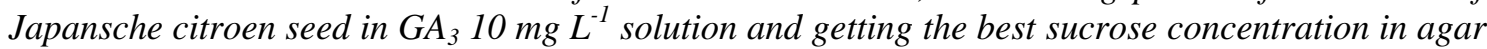
for grafted plant. The experiment was conducted at the in vitro Laboratory of Cell and Tissue Biology, BB Biogen, and Plant Tissue Culture Laboratory, Faculty of Agriculture, Bogor Agricultural University from January to September 2014. A completely randomized design (CRD) was used in experiment with 1 treatment factor. The factor was kinetin concentration in multiplication medium (MS $+M W$ Vitamin) consisting of three level of: $\left(K_{1}\right)$ kinetin $1 \mathrm{mg} \mathrm{L}^{-1},\left(K_{2}\right)$

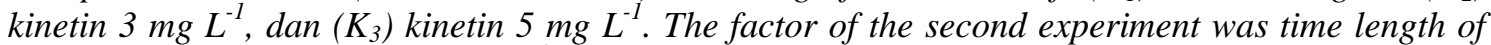
$J C$ seed immersion in $G A_{3} 10 \mathrm{mg} \mathrm{L} L^{-1}$ solution: $\left(\delta_{1}\right) 1$ hour, $\left(\delta_{2}\right) 2$ hours, dan $\left(\delta_{3}\right) 3$ hours. The factor for third step is sucrose concentration in grafted plants medium which consisted of three levels: $\left(G_{1}\right)$ $30 \mathrm{~g} \mathrm{~L}^{-1}$ of sucrose, $\left(G_{2}\right) 50 \mathrm{~g} \mathrm{~L}^{-1}$ of sucrose, and $\left(G_{3}\right) 70 \mathrm{~g} \mathrm{~L}^{-1}$ of sucrose. The optimum concentration of kinetin for scion growth was $1 \mathrm{mg} \mathrm{L}^{-1}$ and for multiplication was $5 \mathrm{mg} \mathrm{L}^{-1}$. The best period for rootstock immersion in $G_{3}$ solution was 3 hours. The best percentage of success in micrografting occured at $70 \mathrm{~g} \mathrm{~L}^{-1}$ sucrose containing medium.
\end{abstract}

Key words: gibberellin, kinetin,multiplication, sucrose

\begin{abstract}
ABSTRAK
Penelitian ini Penelitian ini bertujuan mendapatkan konsentrasi penambahan kinetin terbaik pada multiplikasi jeruk keprok garut hasil induksi mutasi, mendapatkan perlakuan perendaman $\mathrm{GA}_{3}$ terbaik untuk perkecambahan batang bawah Japansche Citroen (JC), dan mendapatkan konsentrasi gula terbaik untuk menumbuhkan tanaman hasil sambung mikro. Penelitian dilaksanakan di Laboratorium in vitro kelompok peneliti Biologi Sel dan Jaringan, Balai Besar Bioteknologi dan Genetika serta Laboratorium Kultur Jaringan, Departemen Agronomi dan Hortikultura, Fakultas Pertanian, Institut Pertanian Bogor pada bulan Januari hingga September 2014. Rancangan penelitian yang digunakan adalah rancangan acak lengkap (RAL)1 faktor untuk ke tiga tahap penelitian. Faktor pada percobaan multiplikasi adalah konsentrasi kinetin pada media multiplikasi (MS+Vitamin MW) yang terdiri atas 3 taraf: $\mathrm{K}_{1}$ ) kinetin $1 \mathrm{~g} \mathrm{~L}^{-1},\left(\mathrm{~K}_{2}\right)$ kinetin $3 \mathrm{~g} \mathrm{~L}^{-1}$, dan $\left(\mathrm{K}_{3}\right)$ kinetin $5 \mathrm{~g} \mathrm{~L}^{-1}$. Faktor untuk percobaan ke dua adalah lama perendaman biji JC pada larutan $\mathrm{GA}_{3} 10$ $\mathrm{mg} \mathrm{L}^{-1}$ yang terdiri atas 3 taraf yakni $\left(\delta_{1}\right) 1 \mathrm{jam},\left(\delta_{2}\right) 2 \mathrm{jam}$, dan $\left(\delta_{3}\right) 3 \mathrm{jam}$. Faktor pada percobaan ke tiga adalah konsentrasi gula pada media tanaman hasil sambung mikro dengan 3 taraf: $\left(\mathrm{G}_{1}\right)$ konsentrasi gula $30 \mathrm{~g} \mathrm{~L}^{-1},\left(\mathrm{G}_{2}\right)$ konsentrasi gula $50 \mathrm{~g} \mathrm{~L}^{-1}$, dan $\left(\mathrm{G}_{3}\right)$ konsentrasi gula $70 \mathrm{~g} \mathrm{~L}^{-1}$. Konsentrasi kinetin optimal untuk pertumbuhan batang atas adalah $1 \mathrm{mg} \mathrm{L}^{-1}$ sedangkan untuk kemunculan tunas baru adalah $5 \mathrm{mg} \mathrm{L}^{-1}$. Lama perendaman pada larutan $\mathrm{GA}_{3} 10 \mathrm{mg} \mathrm{L}^{-1}$ yang terbaik untuk memacu perkecambahan biji dan pemanjangan kecambah adalah 3 jam. Persentase keberhasilan sambung mikro tertinggi diperoleh media dengan konsentrasi gula $70 \mathrm{~g} \mathrm{~L}^{-1}$.
\end{abstract}

Kata kunci: giberelin, kinetin, multiplikasi, gula

${ }^{1}$ Departemen Agronomi dan Hortikultura, Fakultas Pertanian, Institut Pertanian Bogor

(Bogor Agricultural University), J1. Meranti, Kampus IPB Darmaga, Bogor 16680, Indonesia

Telp.\&Faks. 62-251-8629353. *Email korespondensi: apurwito@yahoo.com 


\section{PENDAHULUAN}

Jeruk merupakan sumber vitamin C dalam kehidupan manusia. Menurut FAO, satu jeruk memiliki kandungan vitamin $\mathrm{C}$ sebesar $70 \mathrm{mg}$ (konsumsi rekomendasi 30-100 $\mathrm{mg}$ /hari) sehingga satu orang cukup memakan satu jeruk setiap harinya untuk memenuhi kebutuhan vitamin C-nya. Hal ini membuat konsumsi jeruk di Indonesia cukup tinggi terbukti dari kebutuhan impor jeruk di Indonesia yang meningkat tajam dari 100655 ton tahun 2006 menjadi 204148 ton pada tahun 2010 (Badan Pusat Statistika, 2010).

Perbanyakan tanaman jeruk dapat dilakukan secara generatif yakni dengan biji atau dengan vegetatif yakni dengan cangkok maupun sambung. Perbanyakan secara generatif jarang dilakukan karena fase juvenil pada jeruk yang lama (antara 6-20 tahun) (Pena et al., 2001) dan sifat buah yang dihasilkan beragam dan seringkali tidak unggul walaupun berasal dari induk yang unggul. Lamanya fase juvenil dari jeruk memperlambat proses pembuahan jeruk baik secara konvensional maupun nonkonvensional. Pemuliaan mutasi secara in vitro merupakan salah satu teknik non konvensional yang dapat dipilih dalam pemuliaan jeruk. Kendala yang dihadapi dalam teknik ini adalah lambatnya regenerasi tunas putatif mutan sehingga perlu dilakukan upaya untuk mempercepat pertumbuhan tunas tersebut. Penelitian Susanto et al. (2010) mengenai pertumbuhan vegetatif dan generatif batang atas jeruk Pamelo menunjukkan bahwa beberapa 'interstok' berpotensi mendorong pertumbuhan vegetatif tanaman.

Penyambungan mengombinasikan batang bawah dan batang atas dengan keunggulan masing-masing spesies. Batang bawah yang dipakai umumnya memiliki perakaran yang kuat dan tahan terhadap penyakit perakaran tertentu sedangkan batang atas yang dipakai umumnya memiliki produktivitas yang tinggi (Tambing, 2008). Penyambungan pada tanaman jeruk dapat dilakukan secara konvensional maupun secara in vitro Sambung konvensional memiliki masalah terutama dalam ketersediaan batang atas dan batang bawah yang lama karena harus menunggu batang atas dan bawah tumbuh sesuai dengan kriteria sambung (Khan, 2007), permasalahan dalam penanganan penyakit (Roistacher, 2004), dan inkompatibilitas antara batang atas dan batang bawah (Ji-Zhong et al., 2002).

Sambung mikro adalah teknik yang sangat berpotensi karena menggabungkan keuntungan mikro propagasi dengan pertambahan produksi hasil penyambungan batang bawah dan batang atas (Gebhardt dan Goldbach, 1988). Teknik ini bebas dari penyakit karena dilakukan pada kondisi in vitro dan jaringan meristem relatif bebas virus dan patogen (Mudge et al., 2009). Tanaman disambung pada umur yang relatif sangat muda sehingga inkompatibilitas dapat segera terlihat (Obeidy dan Smith, 1991).

Perbanyakan secara in vitro memerlukan zat pengatur tumbuh (ZPT) untuk mengoptimalkan pertumbuhan eksplan. Purnamaningsih dan Lestari (1998) menyatakan bahwa untuk mendapatkan hasil yang optimum maka penggunaan media dasar dan zat pengatur tumbuh yang tepat merupakan faktor yang penting. Oleh karena itu perlu dilakukan studi perbanyakan batang atas, perkecambahan batang bawah, dan optimasi tanaman hasil sambung mikro. Penelitian ini bertujuan mendapatkan konsentrasi penambahan kinetin terbaik pada media multiplikasi jeruk keprok garut hasil induksi mutasi, mendapatkan lama perendaman dalam $\mathrm{GA}_{3}$ terbaik untuk perkecambahan batang bawah Japansche Citroen (JC), dan mendapatkan konsentrasi gula terbaik untuk menumbuhkan tanaman hasil sambung mikro.

\section{BAHAN DAN METODE}

Penelitian dilaksanakan di Laboratorium in vitro kelompok peneliti Biologi Sel dan Jaringan Balai Besar Penelitian dan Pengembangan Bioteknologi dan Sumber Daya Genetika Pertanian serta Laboratorium Kultur Jaringan, Departemen Agronomi dan Hortikultura, Fakultas Pertanian, Institut Pertanian Bogor mulai bulan Januari 2014 hingga September 2014.

Bahan yang digunakan sebagai eksplan dalam penelitian ini adalah tunas hasil induksi mutasi Ethyl Methyl Sulfonate (EMS) pada kalus jeruk keprok garut yang akan diperbanyak dan disambung mikro dengan Japansche Citroen (JC) sebagai batang bawah. Bahan kimia yang digunakan adalah media dasar MS, formulasi vitamin Morel and 
Wetmore (MW), Benzil Adenine (BA), Indol Acetic Acid (IAA), Giberelin Acid ( $\left.\mathrm{GA}_{3}\right)$, Kinetin, bahan sterilisasi (alkohol 96\%, klorox 30\%, dan klorox 10\%), Malt Extract, serta gula pasir.

Penelitian ini terdiri atas 3 Percobaan yaitu (1) Multiplikasi jeruk keprok kandidat mutan pada media dengan penambahan kinetin, (2) Perkecambahan biji Japansche Citroen (JC) dengan perlakuan $\mathrm{GA}_{3}$, (3) Optimasi pertumbuhan tanaman hasil sambung mikro jeruk keprok kandidat mutan dengan JC.

\section{Multiplikasi Jeruk Keprok Kandidat Mutan pada Media dengan Penambahan Kinetin}

Tunas in vitro hasil induksi mutasi dipotong kira-kira 2 buku, dan disubkultur dalam media perlakuan multiplikasi yaitu MS+Vitamin MW+Kinetin $1 \mathrm{mg} \mathrm{L}^{-1}$; media MS+Vitamin MW+Kinetin $3 \mathrm{mg} \mathrm{L}^{-1}$; dan media MS+Vitamin MW+Kinetin $5 \mathrm{mg} \mathrm{L}^{-1}$. Pengamatan dilakukan tiap minggu terhadap tinggi tanaman, jumlah buku, dan jumlah tunas baru. Rancangan percobaan yang digunakan adalah Rancangan Acak Lengkap dengan konsentrasi kinetin sebagai faktornya. Terdapat 3 perlakuan dengan 12 ulangan sehingga terdapat 36 satuan percobaan. Tiap satuan percobaan terdiri atas 3 eksplan.

\section{Perkecambahan Biji Japansche Citroen (JC) dengan Perlakuan $\mathrm{GA}_{3}$}

Buah JC direndam dalam larutan alkohol $96 \%$ selama 1 jam dan dibilas dengan akuades steril. Biji kemudian diambil dari buah dengan pinset dan scalpel dalam laminar air flow cabinet. Biji diperlakukan dalam larutan $\mathrm{GA}_{3} 10 \mathrm{mg} \mathrm{L}^{-1}$ yang telah disterilkan dengan filter milipore selama 1, 2, dan 3 jam. Pengamatan dilakukan tiap minggu terhadap persentase tumbuh dan tinggi tanaman. Rancangan percobaan yang digunakan adalah Rancangan Acak Lengkap dengan lama perendaman $\mathrm{GA}_{3}$ sebagai faktornya. Terdapat 3 perlakuan dengan masing-masing 9 ulangan sehingga terdapat 27 satuan percobaan. Tiap satuan percobaan terdiri atas 5 eksplan.

Optimasi Pertumbuhan Tanaman Hasil Sambung Mikro Jeruk Keprok Kandidat Mutan dengan JC

Tunas batang atas hasil multiplikasi dipotong pucuknya kira-kira sepanjang 2 buku sedangkan batang bawah hasil perkecambahan JC dibuang bagian tunas pucuknya menyisakan bagian hipokotil sepanjang $\pm 3 \mathrm{~cm}$. Bagian pangkal batang atas dipotong membentuk seperti huruf V sedangkan pada batang bawah disayat bagian tengah sepanjang kirakira $0.3 \mathrm{~cm}$. Batang atas kemudian disambungkan/disisipkan dengan batang bawah menggunakan pinset. Tanaman hasil sambung ini kemudian ditanam dalam media MS0 yang ditambahkan gulanya sesuai perlakuan yakni $30 \mathrm{~g} \mathrm{~L}^{-1}, 50 \mathrm{~g} \mathrm{~L}^{-1}$, dan $70 \mathrm{~g} \mathrm{~L}^{-1}$. Pengamatan dilakukan setiap minggu sampai minggu keempat terhadap persentase keberhasilan sambung. Rancangan percobaan yang digunakan adalah rancangan acak lengkap dengan konsentrasi gula pasir sebagai faktornya. Terdapat 3 perlakuan dengan masing-masing 7 ulangan sehingga terdapat 21 satuan percobaan. Tiap satuan percobaan terdiri atas 2 eksplan. Tahapan penyambungan ditunjukkan pada Gambar 1 .
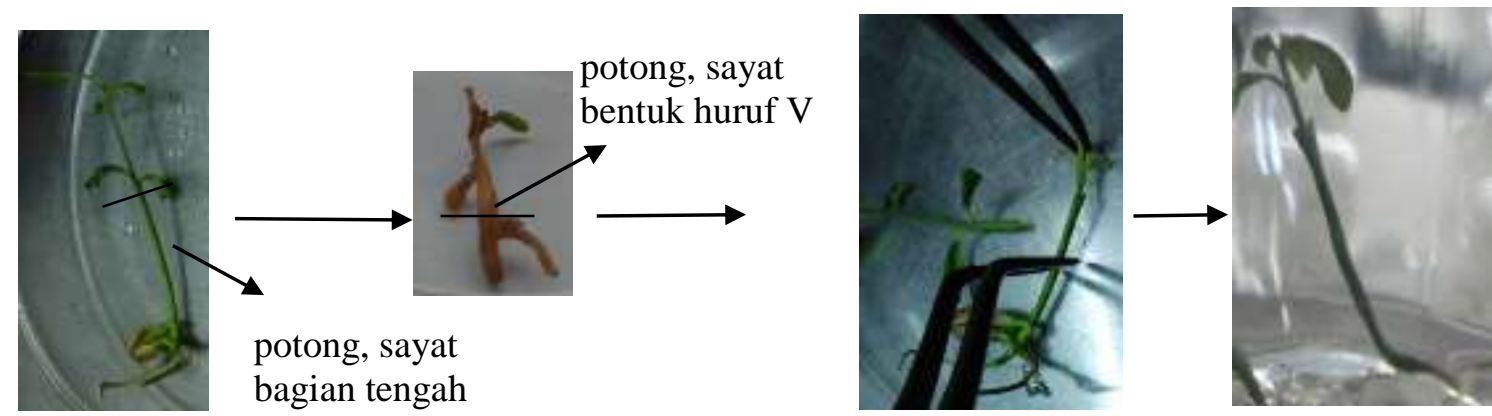

Gambar 1. Skema penyambungan mikro antara tunas putatif mutan jeruk keprok garut (batang atas) dengan jeruk JC (batang bawah) 


\section{HASIL DAN PEMBAHASAN}

\section{Multiplikasi Jeruk Keprok Garut Hasil Mutasi}

Multiplikasi merupakan tahap penting dalam propagasi tanaman. Hal ini bertujuan untuk memperbanyak tanaman yang memiliki sifat yang sama dengan tanaman induk. Multiplikasi dilakukan dengan menginduksi tunas pucuk baru dari tunas samping dan tunas adventif. Pada percobaan ini tunas putatif mutan jeruk keprok dimultiplikasi pada media dasar MS + Vitamin MW yang dikombinasi dengan kinetin pada konsentrasi $1 \mathrm{mg} \mathrm{L}^{-1}, 3$ $\mathrm{mg} \mathrm{L} \mathrm{L}^{-1}$, dan $5 \mathrm{mg} \mathrm{L}^{-1}$. Hasil pengamatan pertumbuhan tunas putatif mutan menunjukkan pertumbuhan yang relatif lambat (Tabel 1). Tunas yang ditumbuhkan pada media dengan penambahan kinetin konsentrasi $1 \mathrm{mg}$ $\mathrm{L}^{-1}$ menunjukkan rata-rata pertambahan tinggi dan jumlah buku yang paling besar dibandingkan dengan kedua perlakuan lain. Rata-rata pertambahan tinggi tanaman pada media kinetin $1 \mathrm{mg} \mathrm{L}^{-1}$ adalah $0.39 \mathrm{~cm}$ dengan pertambahan buku 1.50.

Media dengan penambahan kinetin $5 \mathrm{mg}$ $\mathrm{L}^{-1}$ menunjukkan jumlah tunas terbanyak yakni 1.45 tunas baru per eksplan, tetapi pertambahan tingginya tidak signifikan yakni hanya $0.23 \mathrm{~cm}$ (tabel 2). Sambung mikro memerlukan batang atas dari tunas pucuk sehingga jumlah tunas baru adalah yang terpenting, sehingga tunas yang belum membentuk tunas baru disubkultur pada media dengan penambahan kinetin $5 \mathrm{mg} \mathrm{L}^{-1}$.

Peningkatan konsentrasi kinetin menghambat pertumbuhan batang atas. Tinggi eksplan pada perlakuan kinetin konsentrasi 3 $\mathrm{mg} \mathrm{L}^{-1}$ berbeda nyata dibandingkan dengan konsentrasi $3 \mathrm{mg} \mathrm{L}^{-1}$ dan $5 \mathrm{mg} \mathrm{L}^{-1}$ pada minggu ke tiga dan ke lima. Pertumbuhan eksplan pada kinetin konsentrasi $1 \mathrm{mg} \mathrm{L}^{-1}$ naik pada minggu ke delapan sehingga pertumbuhannya lebih tinggi dibanding eksplan pada kinetin konsentrasi $5 \mathrm{mg} \mathrm{L}^{-1}$. Media dengan penambahan kinetin konsentrasi $3 \mathrm{mg}$ $\mathrm{L}^{-1}$ menginduksi pertumbuhan secara cepat pada awal, tetapi pertumbuhannya melambat setelah minggu ke lima. Hal ini berbeda dengan media dengan konsentrasi kinetin $1 \mathrm{mg}$ $\mathrm{L}^{-1}$ yang menginduksi pertumbuhan lambat pada awal, tetapi nilai pertumbuhan eksplan semakin tinggi tiap minggunya. Ekplan pada media dengan konsentrasi kinetin $5 \mathrm{mg} \mathrm{L}^{-1}$ memiliki nilai pertumbuhan yang paling rendah dibandingkan dengan kedua perlakuan lain. Hal ini diduga karena konsentrasi kinetin yang berlebihan cenderung menghambat pertambahan tinggi tanaman. Kinetin dikenal sebagai faktor dalam pembelahan sel sehingga jumlah yang tepat dapat menginduksi pembelahan sel sehingga dapat memicu pertambahan tinggi tanaman.

Tabel 1. Pertumbuhan tunas keruk keprok putatif mutan pada media multiplikasi tunas dengan penambahan kinetin 8 minggu setelah dikulturkan

\begin{tabular}{lccc}
\hline Media & Jumlah tunas & Tinggi $(\mathrm{cm})$ & Jumlah buku \\
\hline Kinetin $1 \mathrm{mg} \mathrm{L}^{-1}$ & $1.1 \pm 0.6$ & $0.4 \pm 0.2$ & $1.5 \pm 1.1$ \\
Kinetin $3 \mathrm{mg} \mathrm{L}^{-1}$ & $0.8 \pm 0.7$ & $0.4 \pm 0.2$ & $0.8 \pm 0.7$ \\
Kinetin 5 mg L & $1.5 \pm 1.3$ & $0.2 \pm 0.1$ & $1.1 \pm 0.8$ \\
\hline
\end{tabular}

Tabel 2. Rata-rata pertambahan tinggi tunas jeruk keprok putatif mutan

\begin{tabular}{lccc}
\hline \multirow{2}{*}{ Media } & \multicolumn{3}{c}{ Umur (MST) } \\
\cline { 2 - 4 } & 3 & 5 & 8 \\
\hline & $\ldots \ldots \ldots \ldots \ldots \ldots \ldots \ldots \ldots \ldots \ldots \ldots \ldots \ldots \ldots \ldots \ldots \ldots \ldots \ldots \ldots \ldots \ldots \ldots \ldots \ldots \ldots \ldots \ldots \ldots \ldots \ldots \ldots \ldots \ldots$ \\
Kinetin $1 \mathrm{mg} \mathrm{L}^{-1}$ & $1.09 \mathrm{ab}$ & $1.26 \mathrm{ab}$ & $1.56 \mathrm{a}$ \\
Kinetin $3 \mathrm{mg} \mathrm{L}^{-1}$ & $1.31 \mathrm{a}$ & $1.43 \mathrm{a}$ & $1.53 \mathrm{ab}$ \\
Kinetin $5 \mathrm{mg} \mathrm{L}^{-1}$ & $1.05 \mathrm{~b}$ & $1.16 \mathrm{~b}$ & $1.35 \mathrm{~b}$ \\
\hline Uji F & $*$ & $* *$ & $*$ \\
\hline KK & $22.26^{\mathrm{T}}$ & $16.59^{\mathrm{T}}$ & $14.45^{\mathrm{T}}$ \\
\hline
\end{tabular}

Keterangan: a Angka pada kolom yang sama, diikuti oleh huruf yang sama tidak berbeda nyata pada taraf uji 5\% (uji selang berganda Duncan), KK=Koefisien Keragaman, ${ }^{(\mathrm{T})}=$ hasil transformasi log $(100 * \mathrm{x})$ MST=Minggu Setelah Tanam 


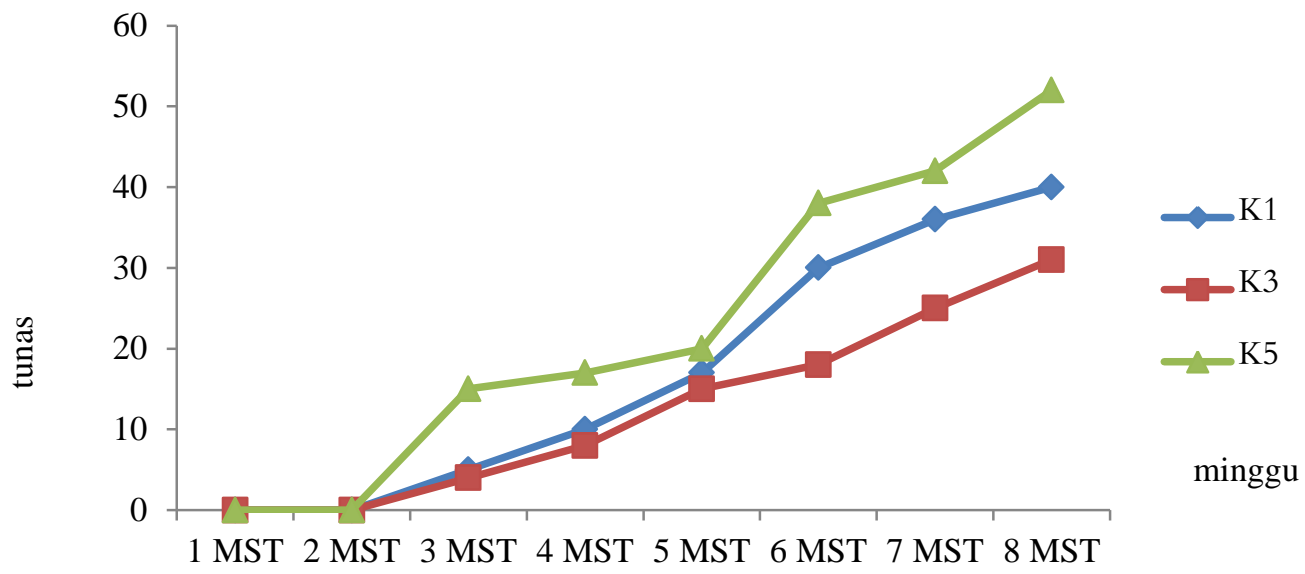

Gambar 2. Jumlah tunas jeruk putatif mutan per minggu pada media multiplikasi tunas. $\mathrm{K} 1=$ Kinetin $1 \mathrm{mg} \mathrm{L}^{-1}, \mathrm{~K} 3=$ Kinetin $3 \mathrm{mg} \mathrm{L}^{-1}, \mathrm{~K} 5=$ Kinetin $5 \mathrm{mg} \mathrm{L}^{-1}$.

Kinetin berperan dalam menginduksi tunas baru dan telah terbukti dalam menginduksi tunas baru pada ubi kayu (Khumaida et al., 2011), Purwoceng (Darwati dan Roostika, 2006), dan Seruni. Lestari (2011) menyatakan bahwa penggunaan zat pengatur tumbuh sitokinin (BA atau kinetin) dapat memacu pertumbuhan tunas baru. Pada tunas putatif mutan jeruk keprok, tunas baru mulai terbentuk pada minggu ketiga. Gambar 2 menunjukkan kinetin $5 \mathrm{mg} \mathrm{L}^{-1}$ menginduksi tunas baru paling banyak setiap minggunya dibandingkan dengan kinetin $1 \mathrm{mg} \mathrm{L}^{-1}$ dan 3 $\mathrm{mg} \mathrm{L} \mathrm{L}^{-1}$. Kinetin $5 \mathrm{mg} \mathrm{L}^{-1}$ menginduksi pembentukan 53 tunas baru sedangkan kinetin $1 \mathrm{mg} \mathrm{L}^{-1}$ dan $3 \mathrm{mg} \mathrm{L}^{-1}$ hanya menghasilkan 38 dan 30 tunas baru pada minggu ke 8 setelah kultur. Hesar et al. (2011) menyatakan bahwa konsentrasi kinetin berbanding lurus dengan pertambahan jumlah tunas baru, jadi dengan peningkatan konsentrasi kinetin dapat memacu pertambahan tunas.

Multiplikasi dapat dilakukan dengan memperbanyak tunas samping sehingga jumlah buku mempengaruhi berapa banyak tanaman bisa diperbanyak. Eksplan pada media dengan konsentrasi kinetin $1 \mathrm{mg} \mathrm{L}^{-1}$ menghasilkan buku terbanyak dibandingkan dengan kinetin $3 \mathrm{mg} \mathrm{L}^{-1}$ dan $5 \mathrm{mg} \mathrm{L}^{-1}$. Ratarata satu eksplan yang dikulturkan pada media dengan penambahan kinetin $1 \mathrm{mg} \quad \mathrm{L}^{-1}$ menghasilkan 1.5 buku per tunas. Hasil ini lebih baik dibanding dengan kinetin $3 \mathrm{mg} \mathrm{L}^{-1}$ dan $5 \quad \mathrm{mg} \mathrm{L}^{-1}$ yang rata-rata hanya menghasilkan 0.8 dan 1.1 buku per eksplan dalam periode 8 minggu pengkulturan. Ilustrasi multiplikasi tunas disajikan pada Gambar 3.

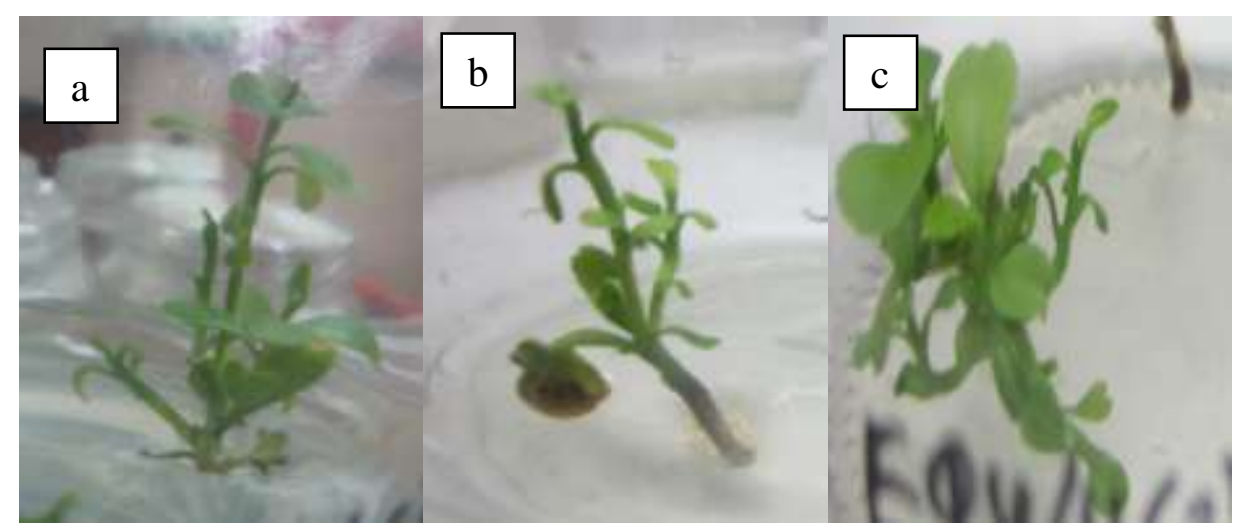

Gambar 3. Multiplikasi jeruk keprok garut putatif mutan pada media dengan penambahan kinetin $1 \mathrm{mg} \mathrm{L}^{-1}$ (a), $3 \mathrm{mg} \mathrm{L}^{-1}$ (b), dan $5 \mathrm{mg} \mathrm{L}^{-1}$ (c) 


\section{Perkecambahan Biji Japansche Citroen (JC)}

Benih JC yang dipakai diperoleh dari Balai Penelitian Tanaman Jeruk dan Buah Subtropika yang masih sangat muda yakni berumur 5 bulan setelah antesis dengan daya berkecambah yang kurang dari 50\%, sehingga diperlukan perlakuan untuk meningkatkan daya berkecambahnya. Hasil perlakuan menunjukkan bahwa perendaman dalam larutan $\mathrm{GA}_{3}$ menunjukkan pengaruh positif dengan meningkatnya persentase perkecambahan. Pada Gambar 4 terlihat bahwa semakin lama perendaman akan meningkatkan persentase perkecambahan benih JC. Daya berkecambah meningkat menjadi $52 \%$ pada perendaman 1 jam, 56\% pada perendaman 2 jam, dan $71 \%$ pada perendaman $3 \mathrm{jam}$. Hal ini menunjukkan bahwa sampai 3 jam setelah perlakuan dalam larutan, $\mathrm{GA}_{3}$ baru bisa menembus testa. Testa jeruk dapat disayat untuk memudahkan masuknya larutan ke dalam benih, tetapi menyayat jeruk yang baru saja dikeluarkan dari dalam buah sangat licin sehingga sulit membuat luka yang tipis. Pelukaan terlalu dalam juga dapat mengenai embrio dalam benih sehingga benih tidak dapat berkecambah.

$\mathrm{GA}_{3}$ berperan penting dalam perkecambahan benih. Giberelin pada benih berukuran kecil/muda merangsang perkecambahan dengan menghilangkan kekangan mekanik yang berasal dari jaringan di sekitar embrio dan mengendurkan dinding sel (Ogawa et al., 2003). Giberelin endogen pada epitelium merangsang perkecambahan dengan menginduksi $\alpha$-amilase sehingga cadangan makanan cepat terserap benih (Kaneko et al., 2002). Perendaman benih dalam larutan giberelin telah diketahui dapat memecahkan dormansi pada benih padi (Vieira et al., 2002). Larutan $\mathrm{GA}_{3}$ hasil perendaman dapat kembali dipakai dengan mensterilkan larutan dengan filter milipore sehingga lebih ekonomis dibandingkan penambahan $\mathrm{GA}_{3}$ pada media, namun perlu diteliti lebih lanjut tentang aktifitas $\mathrm{GA}_{3}$ yang yang dipakai berulang.

$\mathrm{GA}_{3}$ berpengaruh terhadap pemanjangan kecambah. Eksplan pada perendaman $\mathrm{GA}_{3}$ selama 3 jam memiliki pertumbuhan yang terbaik dibandingkan pertumbuhan eksplan pada lama perendaman 1 dan 2 jam pada minggu ke enam. Pada minggu ke delapan pertumbuhan eksplan pada ketiga perlakuan tidak menunjukkan perbedaan yang nyata meskipun hasil paling tinggi tetap pada eksplan dengan lama perendaman 3 jam (Gambar 5). Little dan McDonald (2003) menyatakan bahwa giberelin dapat menstimulasi aktivitas dari meristem subapikal dan meristem apikal sehingga semakin tua umur benih maka semakin sedikit jaringan meristem sehingga efek giberelin dalam memicu pertumbuhan semakin lama akan semakin berkurang. Hal ini juga diduga karena giberelin yang diberikan hanya pada pra tanam sehingga semakin lama giberelin yang tersisa pada jaringan akan berkurang.

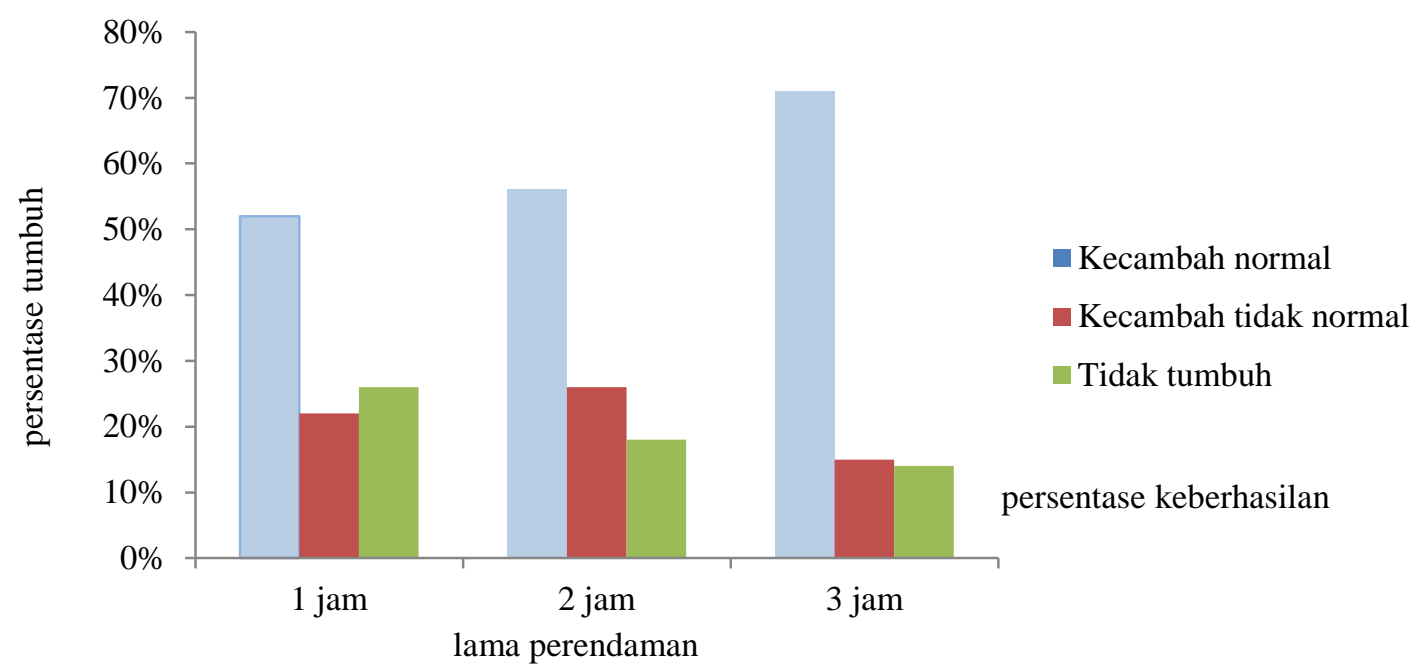

Gambar 4. Persentase perkecambahan benih JC setelah diberi perlakuan $\mathrm{GA}_{3} 10 \mathrm{mg} \mathrm{L}^{-1}, 8$ minggu setelah dikulturkan. 
Tabel 3. Rata-rata pertambahan tinggi kecambah JC hasil perlakuan dengan $\mathrm{GA}_{3}, 5$ dan 8 minggu setelah pengkulturan

\begin{tabular}{ccc}
\hline Lama & \multicolumn{2}{c}{ Umur (MST) } \\
\cline { 2 - 3 } $\begin{array}{l}\text { perendam } \\
\text { an (jam) }\end{array}$ & 6 & 8 \\
& & \\
1 & $\ldots \ldots \ldots \ldots \ldots . \ldots m \ldots \ldots \ldots$ \\
2 & $2.58 \mathrm{a}$ & 4.43 \\
3 & $3.46 \mathrm{a}$ & 4.56 \\
\hline Uji F & $3.92 \mathrm{~b}$ & 5.07 \\
\hline KK & $* *$ & tn \\
\hline Keterangan & 29.29 & 22.66 \\
\hline
\end{tabular}

Keterangan: ${ }^{a}$ Angka pada kolom yang sama, diikuti oleh huruf yang sama tidak berbeda nyata pada taraf uji 5\% (uji selang berganda Duncan), KK=Koefisien Keragaman.

\section{Sambung Mikro Batang Atas Jeruk Keprok Garut dengan Batang Bawah JC}

Gula merupakan salah satu faktor penting dalam keberhasilan kultur secara in vitro. Pierik (1987) menyatakan bahwa pertumbuhan dan perkembangan tanaman dalam in vitro berbanding lurus dengan konsentrasi gula sampai pada konsentrasi tertentu. Tanaman hasil sambung mikro memerlukan energi yang tinggi untuk menstimulasi pertumbuhan sel di antara jaringan yang baru disambung terutama jaringan transportasi antara kedua bagian tanaman tersebut. Hal ini menyebabkan pentingnya penambahan gula lebih tinggi dari biasanya untuk meningkatkan keberhasilan sambung mikro. Gambar 6 menunjukkan bahwa tingkat keberhasilan sambung mikro tergolong tinggi (di atas 80\%). Teknik sambung mikro memiliki tingkat keberhasilan yang lebih tinggi karena jaringan eksplan berupa jaringan meristem yang masih aktif membelah sehingga lebih cepat menstimulasi pemulihan di daerah hasil sambungan (Naz et al., 2007). Semakin tinggi konsentrasi gula, semakin tinggi pula keberhasilan sambung mikro. Penambahan gula konsentrasi $70 \mathrm{mg}$ $\mathrm{L}^{-1}$ memiliki persentase keberhasilan $96 \%$ sedangkan pada gula konsentrasi $50 \mathrm{mg} \mathrm{L}^{-1}$ persentase keberhasilan $89 \%$ dan pada gula konsentrasi $30 \mathrm{mg} \mathrm{L}^{-1}$ hanya $87 \%$. Gambar 7 dan Gambar 8 menunjukkan bahwa semakin tinggi konsentrasi gula pada media, juga menginduksi pembentukan tunas samping batang bawah. Apabila terlalu banyak tunas samping dapat menghambat pertumbuhan tunas sambung.

Hambatan dalam teknik sambung mikro adalah dominansi apikal yang diinduksi auksin terhenti pada batang bawah dikarenakan pucuk dipotong sehingga memicu pertumbuhan tunas samping batang bawah. Hal ini menimbulkan terhambatnya pertumbuhan batang atas. Pada penelitian ini pertumbuhan 1 sampai 2 tunas samping tidak menghambat pertumbuhan batang atas hasil sambungan (data tidak ditampilkan). Semakin tinggi konsentrasi gula juga semakin meningkatkan pertumbuhan batang atas setelah penyambungan. Hal ini menunjukkan bahwa pertumbuhan batang atas dan keberhasilan sambungan tidak terhambat sepenuhnya dengan kemunculan tunas samping.
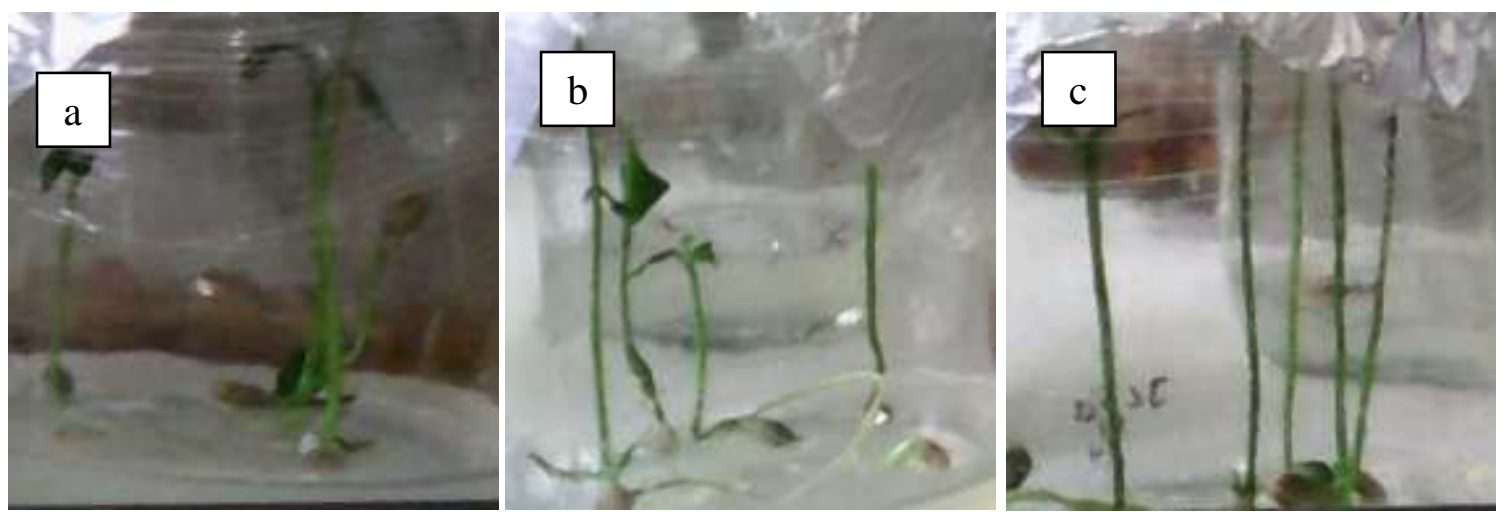

Gambar 5. Perkecambahan benih JC setelah diberi perlakuan $\mathrm{GA}_{3} 10 \mathrm{mg} \mathrm{L}^{-1}, 8$ minggu setelah dikulturkan; perendaman 1 jam (d), 2 jam (e), 3 jam (f) 


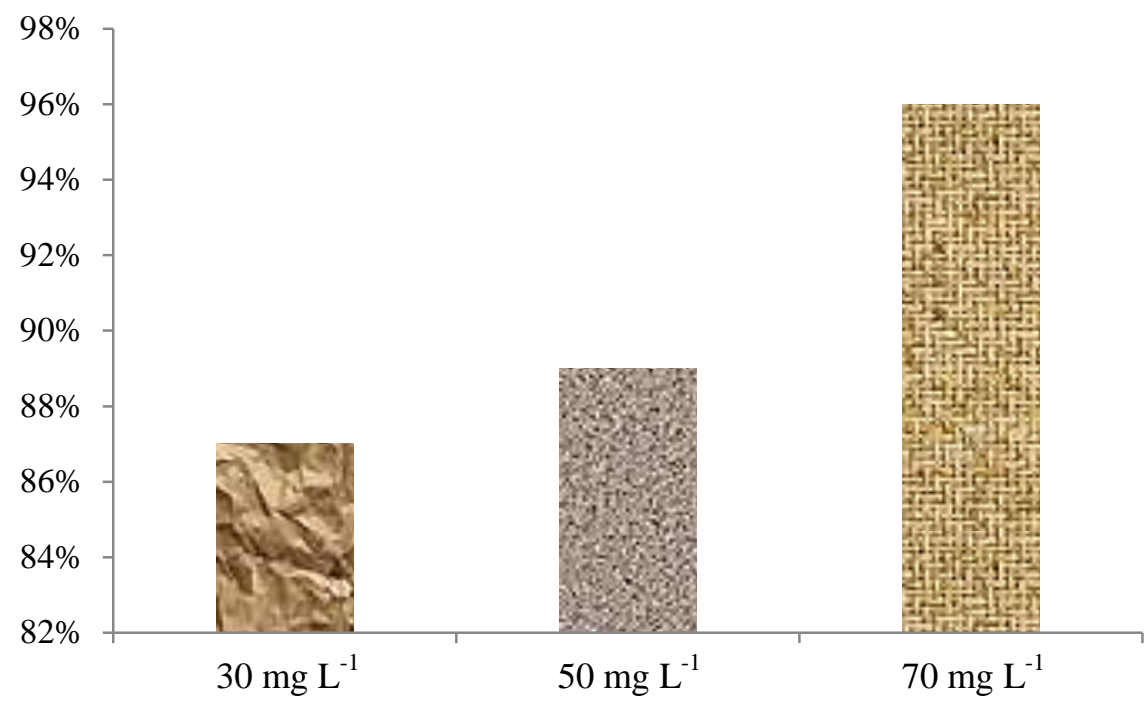

Gambar 6. Persentase keberhasilan sambung mikro antara tunas jeruk keprok putatif mutan dengan batang bawah JC, 8 minggu setelah pengkulturan.

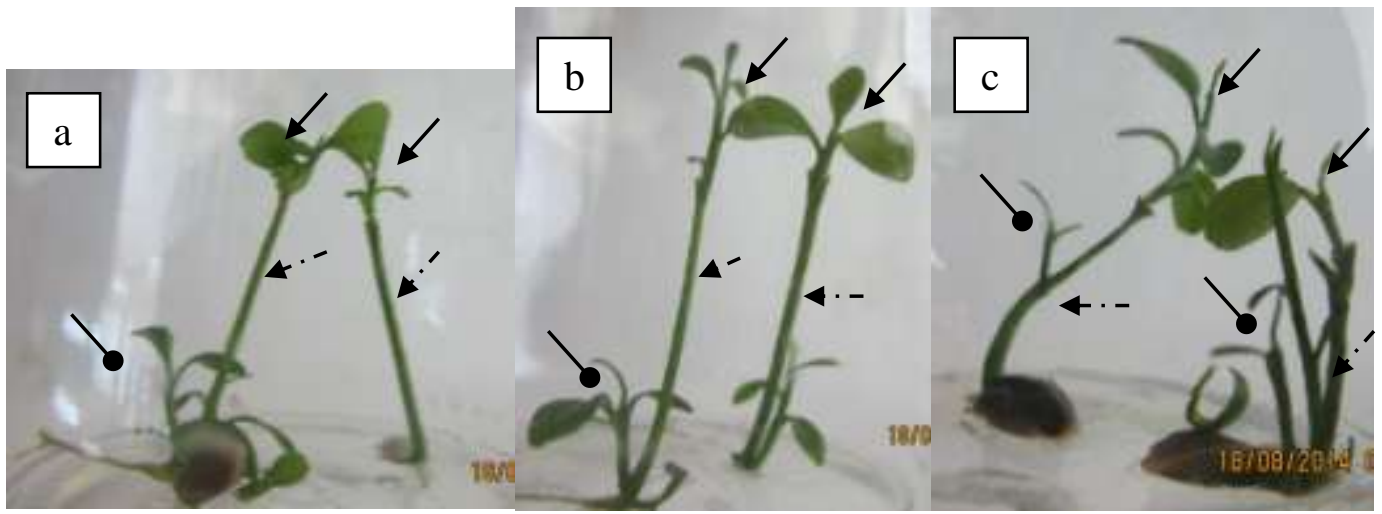

Gambar 7. Pertumbuhan sambung mikro antara tunas jeruk keprok putatif mutan dengan batang bawah JC pada media dengan peningkatan konsentrasi gula $30 \mathrm{~g} \mathrm{~L}^{-1}$ (a), $50 \mathrm{~g} \mathrm{~L}^{-1}$ (b), dan $70 \mathrm{~g} \mathrm{~L}^{-1}$ (c) $\boldsymbol{\iota}^{\prime}=$ batang atas, $\boldsymbol{\sigma}=$ batang bawah, $\boldsymbol{\swarrow}=$ tunas samping.

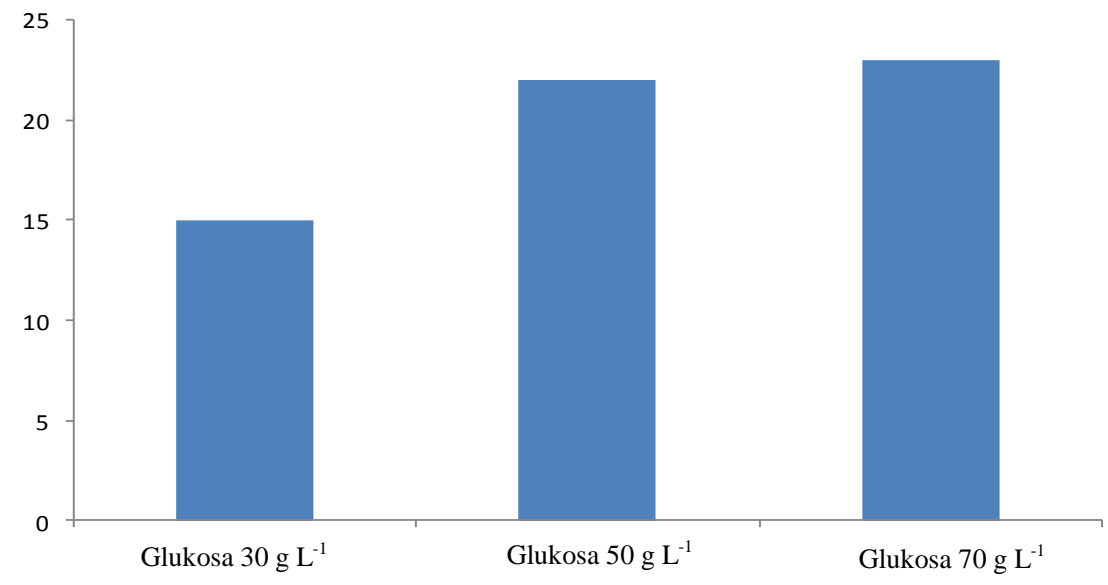

Gambar 8. Jumlah tunas samping batang bawah. 


\section{KESIMPULAN}

Konsentrasi kinetin optimal untuk menginduksi tunas baru adalah $5 \mathrm{mg} \mathrm{\textrm {L } ^ { - 1 }}$ sedangkan untuk pertambahan buku kinetin 1 mg L ${ }^{-1}$ lebih efektif. Lama perendaman $\mathrm{GA}_{3}$ $10 \mathrm{mg} \mathrm{L}^{-1}$ yang terbaik untuk meningkatkan perkecambahan benih dan pemanjangan kecambah adalah 3 jam. Persentase keberhasilan sambung mikro tertinggi pada sambung mikro yang dikulkturkan pada media dengan konsentrasi gula $70 \mathrm{~g} \mathrm{~L}^{-1}$.

\section{DAFTAR PUSTAKA}

Badan Pusat Statistika. 2010. Import BuahBuahan Indonesia 2006-2010. www. bps. go.id [4 Mei 2013]

Darwati, I., I. Roostika. 2006. Status penelitian purwoceng (Pimpina alpina Molk.) di Indonesia. Bul. Plasma Nutfah. 12(1):915.

Gebhardt, K., H. Goldbach. 1988. Establishment, graft union characteristics and growth of Prunus micrografts. Phys. Plant. 72: 153-159.

Hesar, A., K. Behzad, T. Alireza, B. Sahar. 2011. Effect of different concentrations of kinetin on regeneration of ten weeks (Matthiola incana). Plant Omics J. 4(5): 236-238.

Ji-Zhong, X., S.B. Sheng, M. Bao-kun, G. Run-Fang, L. Xiao-Dong, Z. Xian-Bin. 2002. Studies on the POD and IOD activities of the dwarfing stocks and the Red Fuji apple grafted on corresponding interstocks. China. Agric. Sci. 1(5): 562-567.

Kaneko, M., H. Itoh, M. Tanaka, M. Ashikari, M. Matsuoka. 2002. The $\alpha$-amylase induction in endosperm during rice seed germination is caused by gibberellin sythesized in epithelium. Plant Physiol. 128: $1264-1270$.

Khan, I. 2007. Citrus Genetics, Breeding and Biotechnology. Khan I, editor. CABI. Wallingford (GB).
Khumaida, N., S. Ardie, C. Nugroho, Suwarto. 2011. Kinetin and calcium pantothenate effect on shoot multiplication in in vitro cultured Cassava var. Adira 2 and Adira 4. Proceedings of the 7th ACSA Conference.

Lestari, E.G. 2011. Peranan zat pengatur tumbuh dalam perbanyakan tanaman. J. Agrobiogen. 7(1): 63-68.

Little, C., J. McDonald. 2003. Effects of exogenous gibberellin and auxin on shoot elongation and vegetative bud development in seedlings of Pinus sylvestris and Picea glauca. Tree Physiol. 23(2): 73-83.

Mudge, K., J. Janick, S. Scofield, E. Goldschmidt. 2009. History of grafting. Horticultural Reviews. 35: 437-493.

Naz, A., M. Jaskani, H. Abbas, M. Qasim. 2007. In vitro studies on micrografting technique in two cultivars of citrus to produce virus free plants. Pak. J. Bot. 39(5): 1773-1778.

Obeidy, A., M. Smith. 1991. A versatile new tactic for fruit tree micrografting. Hort. Technology. p. 91-94.

Ogawa, M., A. Hanada, Y. Yamauchi, A. Kuwahara, Y. Kamiya, S. Yamaguchi. 2003. Gibberellin biosynthesis and response during Arabidopsis seed germination. The Plant Cell. 15: 15911604.

Pena, L., M. Trilo, J. Juarez, J. Pina, L. Navarro, J. Zapater. 2001. Constitutive expression of Arabidopsis Leafy or Apetala1 genes in citrus reduces their generation time. Nature Biotechnology. 19: 263-267.

Pierik, R. 1998. In Vitro Culture of Higher Plants. Springer. Manhattan (US).

Purnamaningsih, R., E.G. Lestari. 1998. Multiplikasi tunas temu giring melalui kultur in vitro. Bul. Plasma Nutfah. 1(5): 24-27. 
Roistacher, C. 2004. Diagnosis and Management of Virus and Virus Like Diseases of Citrus. Springer. Houten (NL).

Susanto, S., H. Sugeru, S. Minten. 2010. Pertumbuhan vegetatif dan generatif batang atas jeruk Pamelo 'Nambangan' pada empat jenis interstok. J. Hort. Indonesia 1(2): 53-58
Tambing, Y. 2008. Keberhasilan pertautan sambung pucuk pada mangga dengan waktu penyambungan dan panjang entris berbeda. J. Agro. 15(4): 296-301.

Vieira, A., M. Vieira, A. Fraga, J. Oliveira, C. Santos. 2002. Action of gibberellic acid $\left(\mathrm{GA}_{3}\right)$ on dormancy and activity of $\alpha$ amylase in rice seeds. Rev. bras. sementes. 24(2): 101-103. 